\title{
Agricultural Trading System and Global Food Crisis
}

\author{
https://doi.org/10.21272/sec.4(2).6-20.2018
}

\section{He Shuquan}

\author{
School of Economics, Shanghai University, China
}

\begin{abstract}
This paper summarizes the arguments and counterarguments within the scientific discussion on the issue of agricultural trading system and global food crisis. The main purpose of the research is to identify the relationship between world trading system and 2007-2008 food crisis by discussing some agricultural domestic and trade policies as well as selected World Trade Organization (WTO) agricultural trade rules and provisions that have a bearing on response measures to the soaring food prices. Systematization literary sources and approaches for solving the problem of what contributed to the food crisis indicates that though analysts attributed 2007-2008 global food prices spike to various causes, the crisis has its long-term origins in trade policies and agricultural trading system. The relevance of the decision of this scientific problem is that food security are important to the developing countries, and food security is not determined by where the food is produced, but by whether individuals have access to it. Investigation of the topic on food crisis contributing factors in the paper is carried out in the following logical sequence: the description of the food commodity prices evolution in the historical context, followed by the discussion on agricultural trading system, including domestic trade policies as well as the selected WTO agricultural trade rules, and reflections upon recent development on relevant research, agriculture policy as well as WTO negotiation developments. Methodological tools of the research methods were decades of years of research in the field of agricultural trade and food security. The object of research is the countries in the world, especially WTO members, because namely they are the ones who develop these trading system and policies. The paper presents the results of an empirical analysis, examining global agricultural trade policies and selected World Trade Organization (WTO) agricultural rules in the light of the 2007-2008 global food prices spike, which showed that (1) agricultural trade distortion policies are among the long-term contributors to the recent food prices spike; (2) export restrictions during 2007-2008 played a critical role in pushing the food commodity prices upward; (3) the current WTO rules are weak in effect in disciplining export restrictions on food export. The research empirically confirms and theoretically proves that the most effective trade policy response to high food prices over the long term is greater liberalization around the world, complemented by other domestic policies aiming at increasing agricultural productivity, linking rural communities to markets. The results of the research can be useful for negotiation in agriculture trade and domestic reform on agriculture policies.
\end{abstract}

Keywords: food crisis, trade policy, WTO agricultural rules.

JEL Classification: F13, Q17, Q18.

Cite as: He, Shuquan (2018). Agricultural Trading System and Global Food Crisis. SocioEconomic Challenges, 4(2), 6-20. https://doi.org/10.21272/sec.4(2).6-20.2018.

(C) The Authors, 2018. This article is published with open access at Sumy State University.

\section{Introduction}

World prices for the staple food commodities such as maize, rice, wheat, rose all their way since 2000 and more than doubled between 2000 and 2008. Despite declines in the second half of 2008, prices remain well above the average levels of the past two decades. This development and trend have led to a fuller awareness and heightened concern about food security and food crisis all over the world.

Many analysts attribute the prices spike to such causes: rapid economic and income growth in developing countries, new and increasing demand for food crops, low agricultural productivity, etc. ${ }^{1}$ While there are many factors driving food commodities prices rapid increase, the most important ones are the increases in production costs, the devaluation of the dollar, and the rapid increases in the demand of biofuels on food crops. Other factors include droughts in major producing countries and low stocks following policy changes in major

\footnotetext{
${ }^{1}$ There are many studies on the causes and consequences of the recent rising food prices by international organizations and research bodies.
} 
producing countries. However, in addition to these factors there may have also been an element of market failure due to rising expectations, hoarding, speculation, and restrictions on grain exports (Lin, 2008).

However, the soaring price does not mean it is a global food shortage. In fact, there is enough food to feed the world (IMF, 2008). The problem is that prices have risen to where many people cannot afford. Food security is not determined by where the food is produced, but by whether individuals have access to it (Sen, 1981). Governments can enhance food security by allowing imports of food when prices would otherwise have risen. International trade not only can improve resource allocation efficiency by allowing each country to produce according to its comparative advantage, but also is a cost-effective way to reduce the need for large public reserves at the national level.

Therefore, to some extent, food crisis is pushed by trade policy, both domestic and international. From this point of view, the current spike in global food commodity prices has deep roots in decades of trade-distorting policies (Chauffour, 2008). These policies have encouraged inefficient agricultural production in rich countries and discouraged efficient production in developing countries. High-income countries have historically protected their domestic producers and subsidized inefficient production and dumped surpluses onto global markets. In turn, developing countries have often used trade and other domestic policies to simultaneously tax and protect their agricultural sector, with the net effect in many countries of taxing farmers.

The purpose of this paper is to discuss some agricultural domestic and trade policies as well as selected World Trade Organization (WTO) agricultural trade rules and provisions that have a bearing on response measures to the soaring food prices. Countries around the world facing difficulties are taking a variety of responses to dealt with the food price spike. Some of these measures are policy instruments covered by the WTO rules. There are some concerns that the WTO commitments might bind countries from pursuing such measures as they further push the prices high. However, existing rules may not be adequately binding. One country's policy responses may have adverse effects on other countries. Yet, in other cases, there are no rules within WTO to help countries better cope with food crisis.

I arrange the rest of the paper as follow. The second section describes the food commodity prices evolution in the historical context. The third section is devoted to the discussion on agricultural trading system, discussing the domestic trade policies from developed and developing countries and their impact on agriculture production, as well as the selected WTO agricultural trade rules from the current Agreement on Agriculture and the ongoing negotiation draft texts. The fourth section provides reflections upon recent development on relevant research, agriculture policy as well as WTO negotiation. The last section concludes the paper.

\section{Recent Rising Food Prices and National Policy Responses}

The sharp rising food prices have attracted a great deal of attention in policy-makers, mass media, academic circle and enterprises. Are food commodity prices high? The answer depends. It depends on the food commodity in question, it depends on the period of comparison, and it depends on the term of prices, whether it is nominal or real.

\section{The 25-75 Characterization: Food Prices Spike in the Historical Context}

The recent food commodity prices spike is exceptional when viewed from the perspective of the last decade or so. Figure 1 shows the evolution of monthly world prices of rice, wheat, maize and soybeans from 2000 to 2008. The prices started to rise dramatically from the second half of 2007, and it lasted until the end of the first half of 2008. The so-called "world food crisis" coalesced across the globe in 2007 and early 2008 when the price of rice, corn, wheat, soybeans and food more generally skyrocketed.

However, when put in a longer historical context, the price spike is not alone. In fact, since 1970, over a period of about four decades, there were five food commodity prices spikes. As it is shown in Figure 2, these were in 1974-1976, 1980-1982, 1988-90, 1995-1997 and 2007-2008. Each crisis lasted for about 2 years for a total of 10 years, or about $25 \%$ of the period. For the rest of the $75 \%$ of the time, world food prices could be said to be on decline trend or be depressed. This is the so called "25-75 characterization" of the global food commodity price (Sharma and Konandreas, 2008).

In addition, this point is based on nominal term. The real prices tell another story. In real terms or constant US \$, the recent prices spike "are more like the blips in the 1980s and 1990s than in the 1970s crisis (Piesse and Thirtle, 2009). The prices of wheat, rice, maize and soybeans were far less than the 1973-1974 peaks. With 
FAO's internal data, Piesse and Thirtle (2009) shows that in April 2008, wheat price was at 55\% of the 1970s peak, maize at $41 \%$, rice at $24 \%$ and soybeans at $39 \%$, and that it was more a change from stable to rising prices when food prices started to rise in 2006.

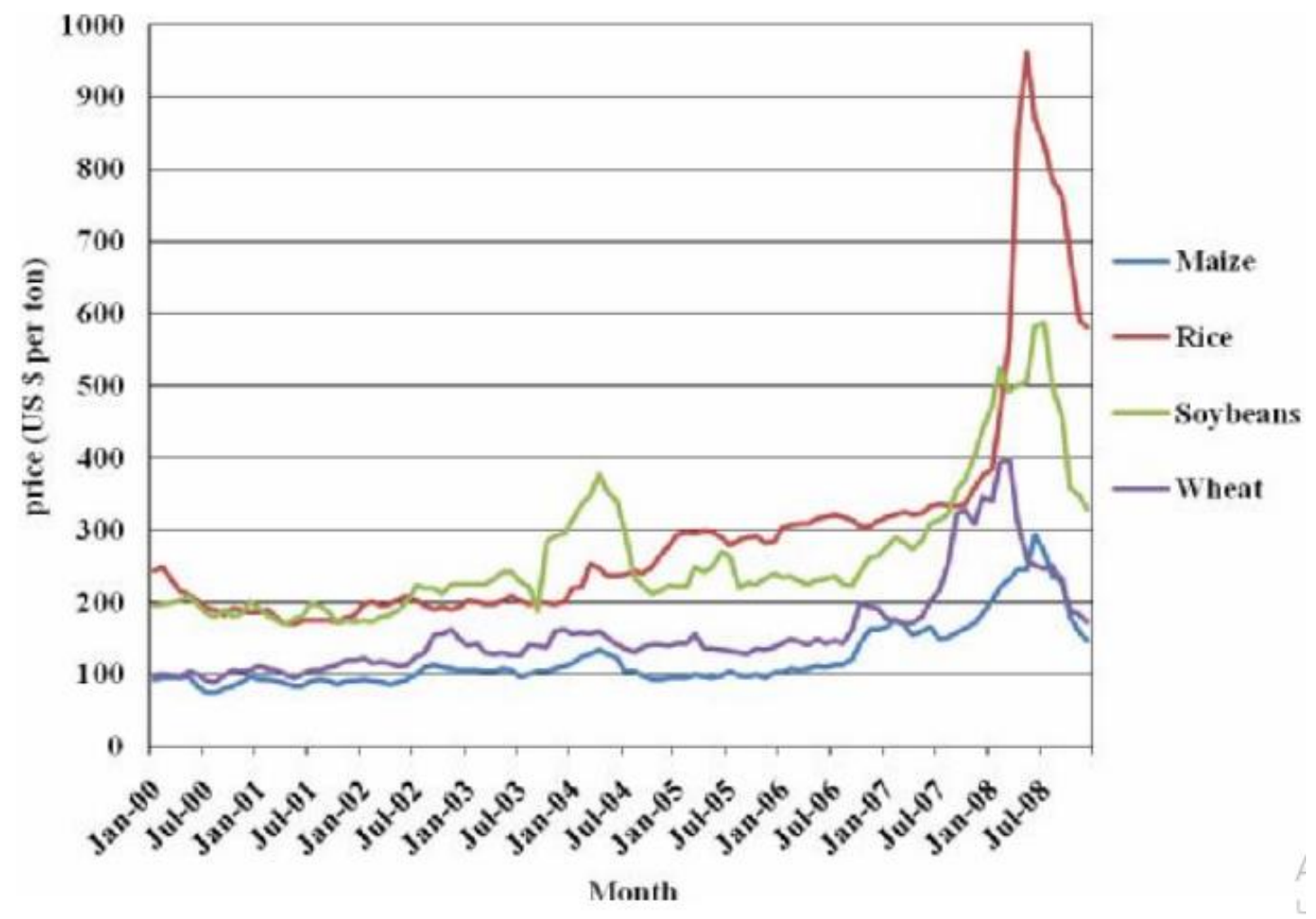

Figure 1. Major Food Commodity Prices, 2000 - 2008 by month

Source: FAO Commodity price Database.

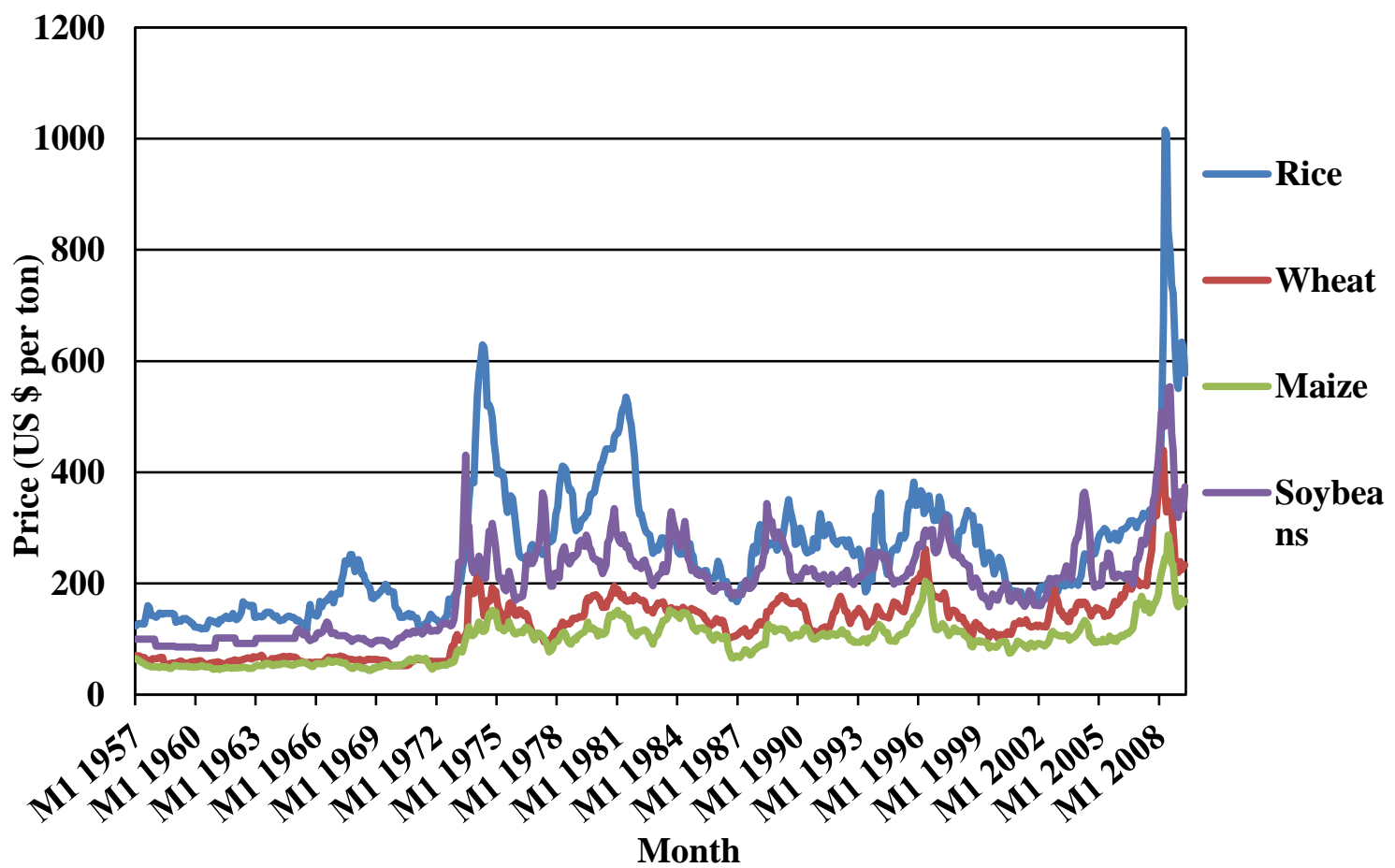

Figure 2. Major Food Commodity Prices, 1967 - 2009 by month

Source: IMF Commodity price Database. 
UNCTAD's price instability index ${ }^{2}$ also confirms the points made by Piesse and Thirtle (2009). Figure 3 describes the instability index over 1968 to 2007 . The instability indices for 1998-2007 are generally smaller than the 1968-1977 period. This suggests that the recent food prices spike may no serious than the one during 1970s.

The first thing to notice from the above texts is that a high degree of price volatility is characteristic in world food commodity markets in nominal terms. It is true even when one looks at annual average prices. Prices are typically sensitive to short run shocks to either supply or demand because of delays between production decisions and output. Volatility on international markets is further enhanced by policy interventions. These policies are designed to shift price risk away from producers or even keep it outside of the country entirely.

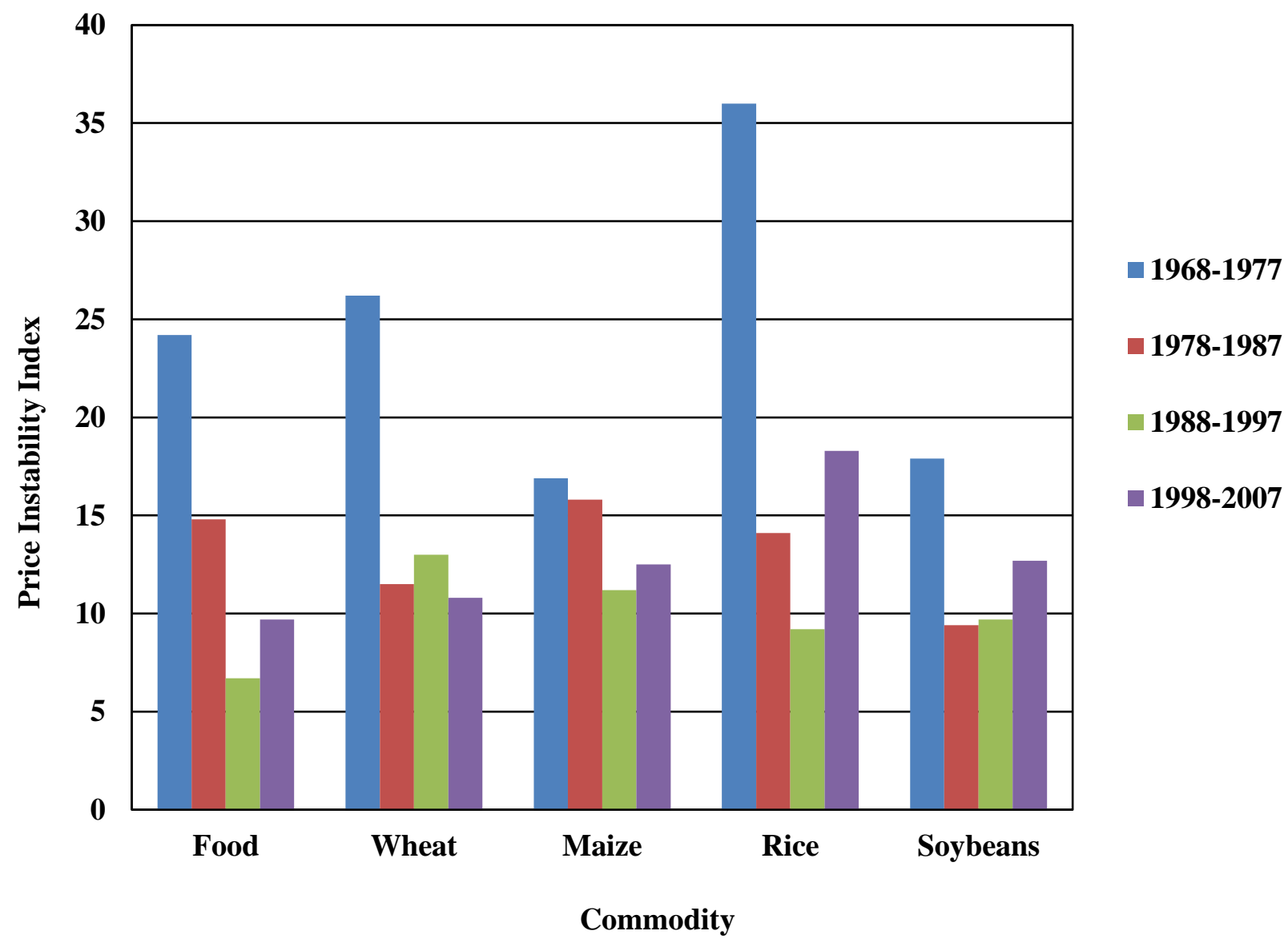

Figure 3. Food Commodity Price Instability Index

Source: UNCTAD Handbook of Statistics 2008 (online).

The second thing to be noticed from Figures 1 to 3 is that the recent food price spike is neither the only, nor the most important one during the last 40 years. In real terms, today's prices fall well below of peaks achieved in the early 1970s, and neither maize nor wheat prices during 2007-2008 are above levels during the mid1990s. Piesse and Thirtle (2009) shows food prices are going on a downward trend in real term. In addition, food prices are more stable during 1998-2007 than during 1968-1977, there are volatile than the previous two decades except for wheat.

\section{Briefs on the Drivers}

Although this is not the only food price spike in the past decades, it has drawn much attention of the governments and economist. It is worth to identify the factors contributing to the high-rising food commodity prices. Figure 4 summarizes the causes for rising food prices and shows that there are great deals of factors driving the prices upward. These factors, as mentioned earlier, include population growth, energy prices, bad weather,

\footnotetext{
${ }^{2}$ Instability is measured as the percentage deviation of the variables concerned from their exponential trend levels for a given period.
} 
etc. Piesse and Thirtle (2009) adds market speculation and panic to this list, and argues that there is a "speculative bubbles for wheat, maize and soybeans" triggered by low-level stock and a "panic for rice" caused by export ban. The export ban of one exporter decreased the rice supply in the world, increased the urgency with rice importers, and raised the price expectation from other exporters (Mitchell, 2008).

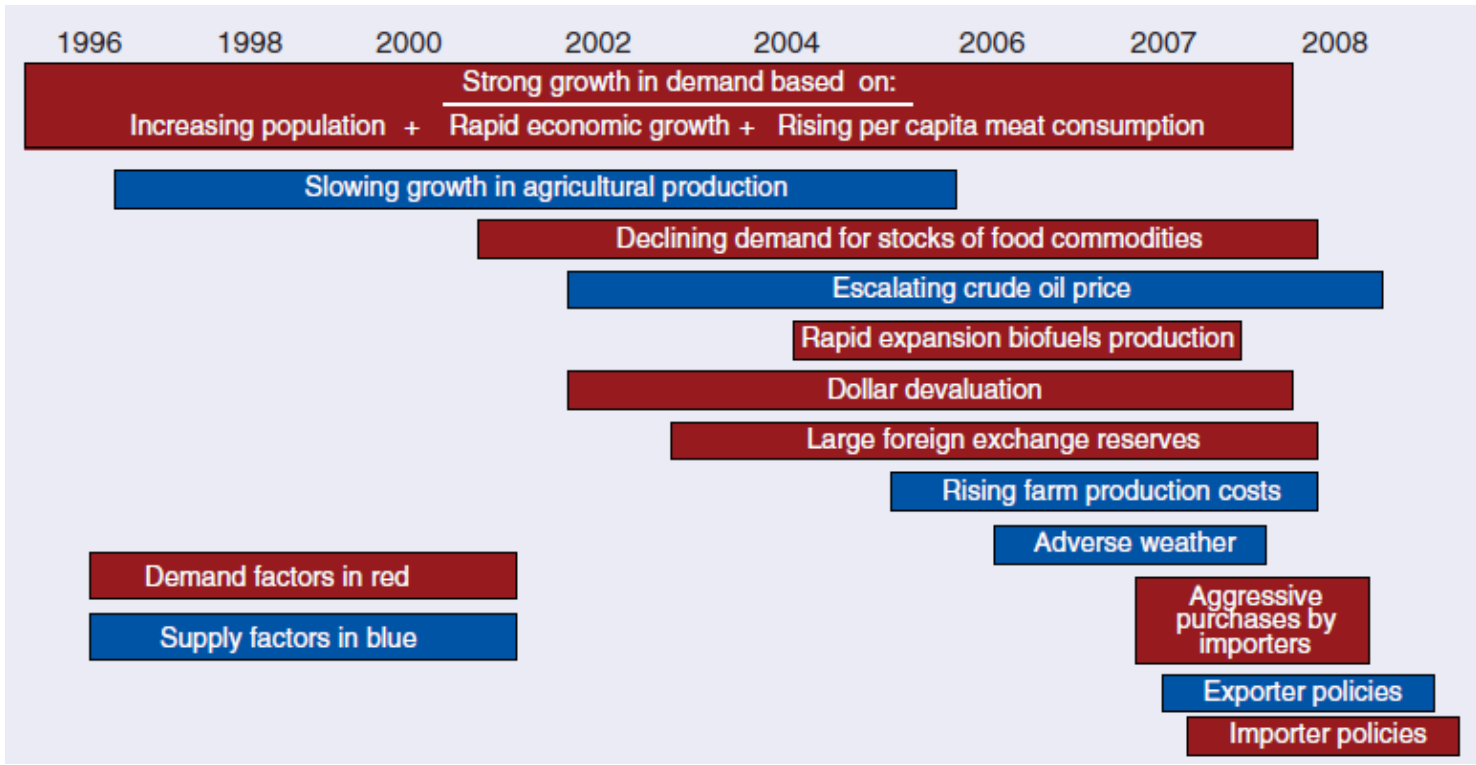

Figure 4. Factors Contributing to Higher Food Commodity Prices

Source: Trostle (2008).

For the purposes of this paper and the sharp-rising periods, we take a closer look at two of them: export and import policies. The national policy responses are discussed in next sub-section.

The rapidly increasing world food commodity prices caused domestic food prices to rise at the consumer level in many countries. In response to rising food prices, some countries began to take protective policies to alleviate the impact of rising world food commodity prices on their own consumers. However, such measures typically force greater adjustments and higher prices onto global markets.

In late 2007, some exporting countries made policy changes designed to discourage exports so as to keep domestic production within the country. The objective was to increase domestic food supplies and restrain increases in food prices. Such policies include eliminating export subsidies, raise or impose export taxes, export quantitative restriction and even export bans.

Early in 2008, importing countries also began to take protective measures to combat rising food prices. Their objective was to make high-cost imports available to consumers at lower prices. The policies include reducing or eliminating tariffs, subsidizing consumers, etc.

\section{National Policy Responses}

Faced with persistently high prices, many governments have tried to limit the increase in domestic food prices by lowering import tariffs, reducing consumer taxes, raising general food subsidies or providing direct food assistance to the needy and vulnerable. Some countries have also resorted to export prohibitions or restrictions of different kinds. According to the World Bank (2008a), more than half $(66.1 \%)$ of 115 countries have taken actions responding to higher food prices as suggested in Figure 5. Among the actioning countries, $64.5 \%$ reduced import taxes on food grain, $40.8 \%$ increase supply using food grain stocks, $40.8 \%$ imposed export restriction, and $60.5 \%$ took actions of price control / consumer subsidy. 


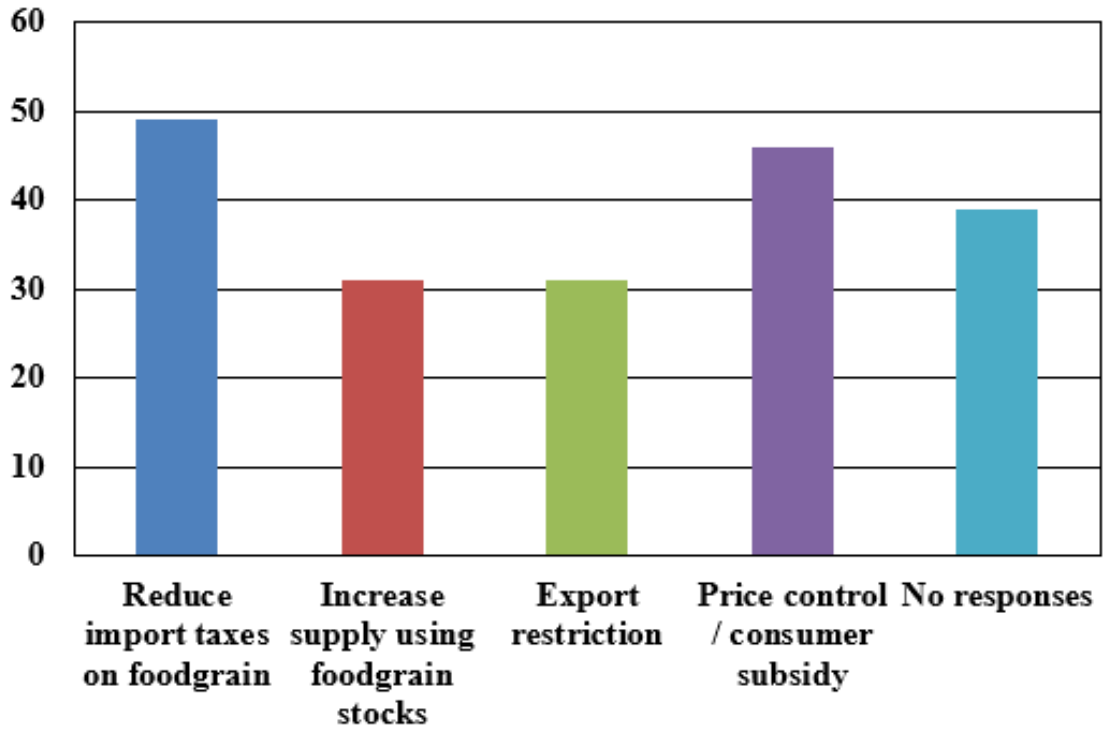

Figure 5. Numbers of Countries Responding to High Food prices, by Policy Type

Source: World Bank (2008a).

A survey by the FAO (2008a, 2008b) on 77 countries suggests that approximately half of the governments reduced grain import taxes, 55 percent of the countries used price controls or consumer, one-quarter of the governments imposed some type of export restriction, and roughly the same proportion took action to increase supply, drawing on food grain stocks. Only 16 percent of countries surveyed showed no policy activities whatsoever.

Policy actions vary considerably by region. Figure 6 reveals that countries in Africa, Eastern Europe and Central Asia had the lowest percentage to respond to the rising food prices. Countries in Middle East and North Africa, and South Asia were the most active ones in this regard.

The FAO survey (2008a) shows that the governments sampled in East Asia, South Asia and the Middle East and North Africa have undertaken significant activities in all four areas of intervention. In every geographical region except sub-Saharan Africa, 50 percent or more of the countries reported using price controls or consumer subsidies. Sub-Saharan Africa and Latin America and the Caribbean regions showed the lowest policy activity, with roughly 20 percent and 30 percent of their countries, respectively, reporting no activity in any of the policy categories listed.

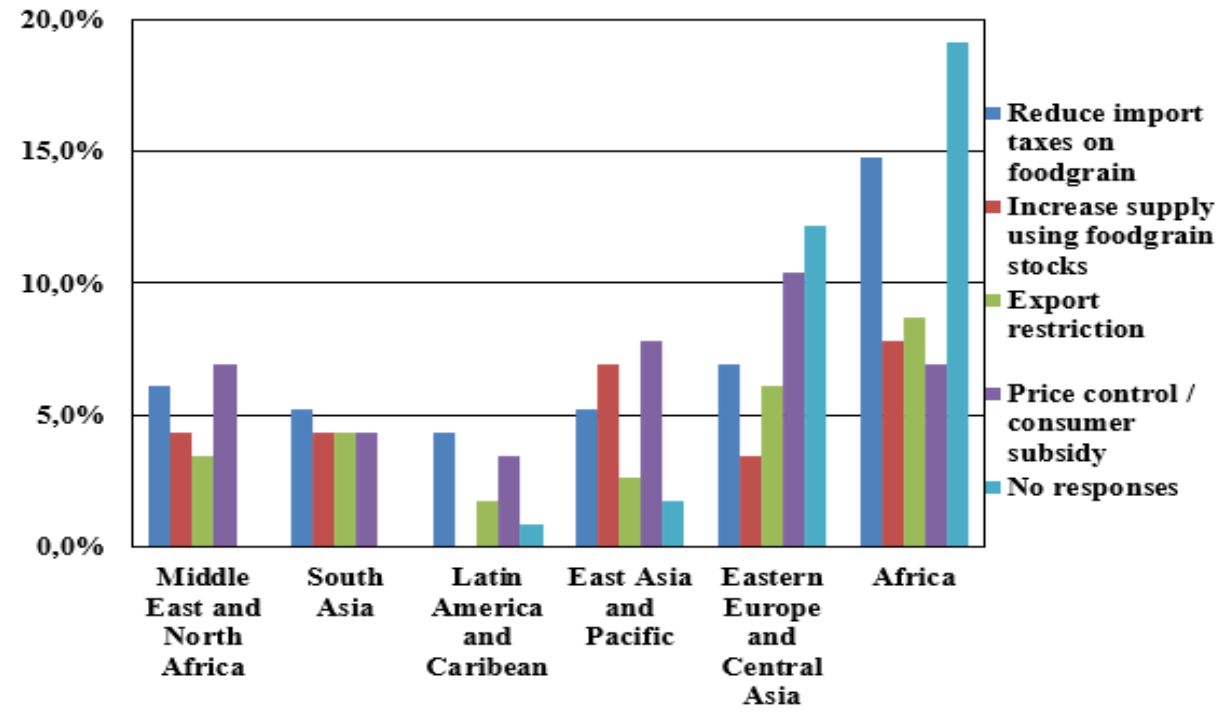

Figure 6. Policy Responses to High Food Prices by Region and Percentage

Source: World Bank (2008a).

Among these policy responses, two are directly related to trade: reductions in import tariffs and export taxation, 
or export restrictions. Reducing or eliminating import tariffs on food products has been the most widespread policy response for stabilizing domestic food prices. Do these measures really work in reducing the soaring food prices? In fact this policy has little effect in practice.

To succeed and have a meaningful impact for this intervention, applied tariffs need to be sufficiently high at the time when world prices begin to rise. It is a common knowledge that despite having relatively high WTO bound tariffs, and applied MFN tariffs on basic foods are relatively low in a majority of the developing countries (WTO, 2008a). Sharma dn Konandreas (2008) suggest that to keep the domestic food prices stablized at the level of 2006, the computed applied tariffs are large negatives. Hence, even when reduced to zero, reductions in tariff levels were able to offset only a small proportion of the overall price rises of food imports.

Export prohibitions, restrictions and export taxation reductions lower domestic prices but also reduce government revenues and producers' income. In addition, export restraints exacerbate price instability in world markets and negatively affect importing countries. Export restrictions also have longer-term implications, as they discourage producers in exporting countries from investing in agriculture.

The introduction of export restrictions on agricultural products by many large food exporters has compounded the crisis. These restrictions usually have major adverse economic and social effects. Export prohibitions and restrictions tend to exacerbate price increases in the world market, while excessive intervention in the domestic market would limit the transmission of higher prices to the farmer. As more countries implement export controls, world prices go up substantially up to 20 percent due to export restrictions, with particularly harmful effects in the case of rice (Chaufour, 2008).

For the purpose of this paper, the effectiveness of these policy responses cannot be discussed in detail. But, clearly, they are mostly welfare reducing - both in the country applying them and in the rest of the worldrelative to direct first-best policy instruments for achieving those domestic objectives (Bhagwati 1971).

\section{Agricultural Trading System}

The current food crisis has deep historical roots in the distortions of the world trading system. Governments have intervened in food and other agriculture markets for decades, particularly through trade policies. Tradedistorting policies have taken the form of tariffs, quantitative restrictions or prohibitions on imports and exports, domestic producer supports, and export subsidies for agricultural products. The various trade agreements and WTO rules further distort agricultural trading system. In this section, I discuss the agricultural distortion policies and their impact on the agricultural production, followed by discussing selected WTO agricultural rules, especially those governing export restrictions.

\section{Agricultural Trade Environment}

It is the pattern since the late $19^{\text {th }}$ century that the higher the level of development of countries, the lower the overall trade restrictiveness, but the higher the level of trade restrictiveness in agriculture (World Bank, 2008b). Table 1 presents the trade restrictiveness indicators by country groups of different income level. While highincome countries have the lowest overall barriers to trade (with overall trade restrictiveness indictor (OTRI) of $7.0 \%$ ), their OTRI for agriculture is $43.1 \%$ as compared to 4.3 for manufacturing, and is the highest among the country groups. In terms of tariff trade restrictiveness indicator (TTRI), it is also the second highest for agriculture. The OTRI for agriculture is even higher of the four major economies (QUAD).

Table 1. OTRI and TTRI by Income Group, 2006 (percentage)

\begin{tabular}{|c|c|c|c|}
\hline & Total Trade & Agriculture & Manufacturing \\
\hline \multirow{2}{*}{ High Income } & $\mathbf{7 . 0}$ & $\mathbf{4 3 . 1}$ & $\mathbf{4 . 3}$ \\
\cline { 2 - 4 } & 2.1 & 12.4 & 1.4 \\
\hline \multirow{2}{*}{ QUAD } & $\mathbf{7 . 1}$ & $\mathbf{4 4 . 5}$ & $\mathbf{4 . 0}$ \\
\cline { 2 - 4 } & 1.9 & 11.1 & 1.3 \\
\hline \multirow{2}{*}{ Middle Upper } & $\mathbf{1 3 . 0}$ & $\mathbf{2 9 . 3}$ & $\mathbf{1 1 . 8}$ \\
\cline { 2 - 4 } & 4.6 & 6.6 & 4.5 \\
\hline \multirow{2}{*}{ Middle Lower } & $\mathbf{1 1 . 8}$ & $\mathbf{2 6 . 5}$ & $\mathbf{1 0 . 6}$ \\
\cline { 2 - 4 } & 6.5 & 11.5 & 6.0 \\
\hline \multirow{2}{*}{ Low Income } & $\mathbf{1 7 . 7}$ & $\mathbf{2 6 . 6}$ & $\mathbf{1 6 . 7}$ \\
\cline { 2 - 4 } & 10.8 & 15.3 & 10.4 \\
\hline
\end{tabular}

Note: TTRI in italics; OTRI in boldface. QUAD comprises Canada, the EU, Japan and the US. Source: World Bank (2008b). 
The EU, United States, Japan, and China account for about 50 percent of world trade. All have policies that are more restrictive of trade in agricultural products than manufactures (Table 2), with Japan and the EU imposing significantly higher restrictions. Manufacturing trade is relatively less restricted: the TTRI is around 1 percent in the EU, Japan, and United States.

Table 2. OTRI and TTRI for the Four Largest Traders, 2006 (percentage)

\begin{tabular}{|c|c|c|c|}
\hline & \multicolumn{3}{|c|}{2006} \\
\hline & Total Trade & Agriculture & Manufacturing \\
\hline \multirow{2}{*}{ United States } & $\mathbf{6 . 4}$ & $\mathbf{1 8 . 4}$ & $\mathbf{5 . 7}$ \\
\cline { 2 - 4 } & 1.6 & 3.8 & 1.5 \\
\hline \multirow{2}{*}{ European Union } & $\mathbf{6 . 6}$ & $\mathbf{4 8 . 7}$ & $\mathbf{2 . 9}$ \\
\cline { 2 - 4 } & 1.4 & 5.9 & 1.1 \\
\hline \multirow{2}{*}{ Japan } & $\mathbf{1 1 . 4}$ & $\mathbf{5 5 . 8}$ & $\mathbf{5 . 7}$ \\
\cline { 2 - 4 } & 4.5 & 31.1 & 1.1 \\
\hline \multirow{2}{*}{ China } & $\mathbf{9 . 9}$ & $\mathbf{1 7 . 1}$ & $\mathbf{9 . 5}$ \\
\cline { 2 - 4 } & 5.1 & 8.8 & 4.9 \\
\hline
\end{tabular}

Note: TTRI in italics; OTRI in boldface font.

Source: World Bank (2008b).

Agricultural trade restrictions and direct subsidies in high-income countries are a major source of support for producers. Although producer support estimates (PSEs) have fallen in some OECD countries since (for example, Japan and the United States), they have increased in the European Union (EU), Korea, and a number of other OECD countries. Figure 7 presents the trends from 1986 to 2008. Support to producers in OECD countries was estimated at US\$258 billion in 2006 and US\$266 billion, accounting for $26 \%$ and $21 \%$ of farm receipts respectively (OECD 2009a).

The indicator used by the World Bank to measure support to agriculture producer is nominal rates of assistance to farmers (NRAs). The World Bank research (Anderson, Kurzweil, et al, 2008; Anderson and Valenzuela, 2008) reveals that in terms of NRAs, the growth of agricultural support in high-income countries began to reverse only in the 1990s. However, if farm income support which is said to be decoupled from production incentives is considered, there is very little decline in the rate of support.

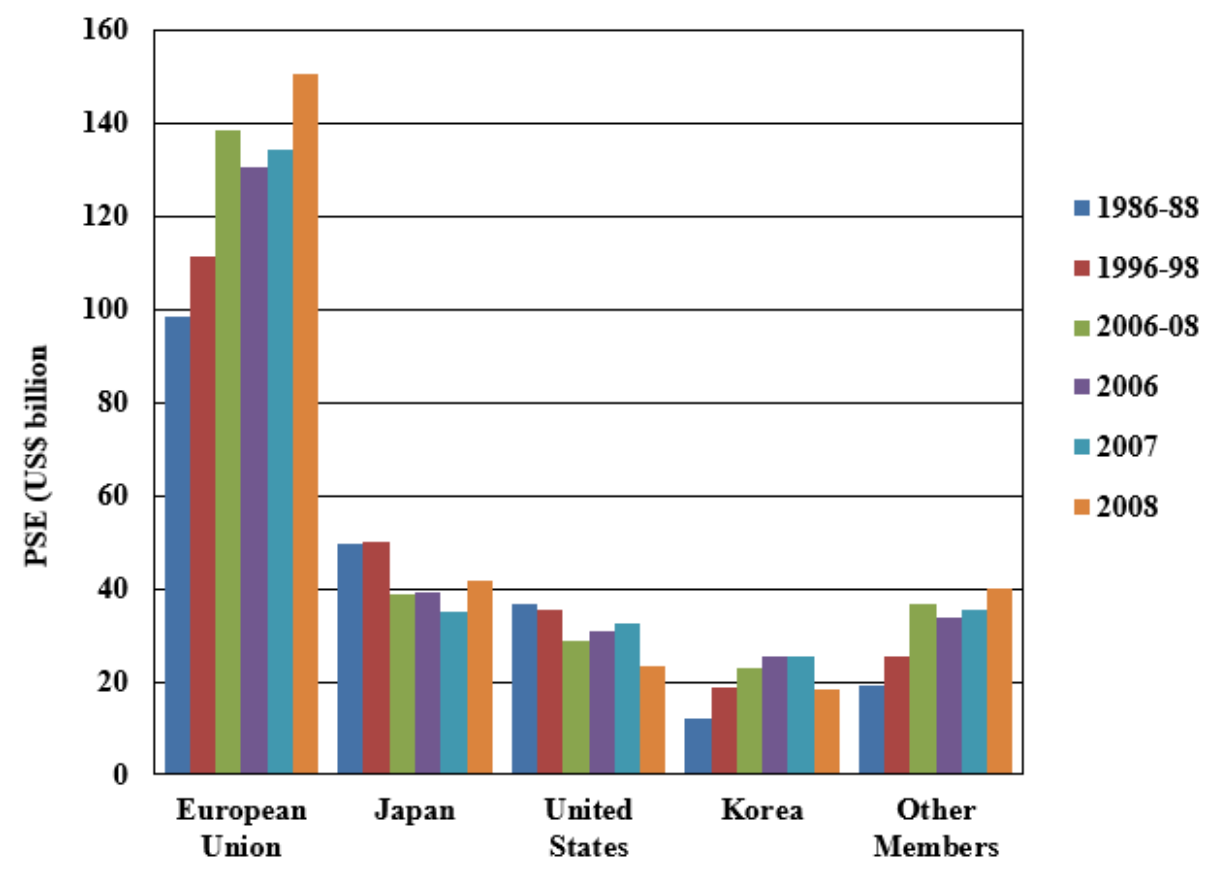

Figure 7. Producer Support Estimates for OECD Countries, 1986 - 2008

Source: OECD PSE/CSE Database, 2009. 
Developing countries have also put in place trade policies that are highly restrictive of trade in agricultural products. All geographic regions have policies that are more restrictive of trade in agricultural products than manufactures, although the levels of trade restrictiveness in agriculture differ widely across regions (Table 3). Countries in South Asia have on average a level of trade restrictiveness in agriculture similar if not higher than that observed in high-income countries. At the other extreme, Sub-Saharan Africa has the lowest level of agriculture trade restrictiveness in the world.

Table 3. OTRI and TTRI for Developing Country by Region and China, 2006 (percent)

\begin{tabular}{|c|c|c|c|}
\hline & Total Trade & Agriculture & Manufacturing \\
\hline \multirow{2}{*}{ East Asia } & $\mathbf{1 1 . 3}$ & $\mathbf{2 6 . 6}$ & $\mathbf{1 0 . 4}$ \\
\cline { 2 - 4 } & 5.0 & 8.7 & 4.8 \\
\hline \multirow{2}{*}{ Europe and Central Asia } & $\mathbf{1 0 . 1}$ & $\mathbf{2 5 . 9}$ & $\mathbf{9 . 0}$ \\
\cline { 2 - 4 } & 4.5 & 10.3 & 4.0 \\
\hline $\begin{array}{c}\text { Latin America } \\
\text { \& Caribbean }\end{array}$ & $\mathbf{1 5 . 0}$ & $\mathbf{2 8 . 1}$ & $\mathbf{1 3 . 8}$ \\
\cline { 2 - 4 } & 5.4 & 6.6 & 5.3 \\
\hline \multirow{2}{*}{ Middle East \& North Africa } & $\mathbf{2 1 . 6}$ & $\mathbf{3 2 . 3}$ & 19.4 \\
\cline { 2 - 4 } & 11.9 & 12.1 & $\mathbf{1 8 . 2}$ \\
\hline \multirow{2}{*}{ South Asia } & $\mathbf{1 9 . 5}$ & $\mathbf{4 6 . 4}$ & 13.2 \\
\hline \multirow{2}{*}{ Sub-Saharan Africa } & 14.0 & 31.4 & $\mathbf{1 2 . 9}$ \\
\cline { 2 - 4 } & $\mathbf{1 4 . 4}$ & $\mathbf{2 4 . 9}$ & 7.6 \\
\hline
\end{tabular}

Note: TTRI in italics; OTRI in boldface font.

Source: World Bank (2008b).

It is a common knowledge that policies in developing countries have generally taxed agriculture to channel resources into manufacturing until recently. The World Bank research (Anderson, Kurzweil, et al, 2008; Anderson and Valenzuela, 2008) supports the widely held view that developing-country governments put in place agricultural policies that effectively taxed their farmers. The extent of taxation was of the order of 20 percent from the mid-1950s to the mid-1980s. Since then, not only has it diminished, but developing countries have moved from taxing to subsidizing their agricultural sector.

The NRAs differs by region for developing countries. African countries have shown the least tendency to reduce the taxing of farmers. The average NRA has been negative in all five-year periods except in the mid1980s, when international prices of farm products reached an all-time low in real terms. By contrast, for both Asia and Latin America, NRAs crossed over from negative to positive after the 1980s. In European transition economies, in the initial years of reform, nominal assistance to farmers was slightly negative, but thereafter it has trended upward (Anderson, Kurzweil, et al, 2008; Anderson and Valenzuela, 2008).

OECD (2009b) reviews the agricultural policy changes of some developing countries such as Brazil, china, Chile and South Africa. The report shows that the PSE in these countries are much lower than that in OECD countries. Support to producers in Chile as measured by the \%PSE has declined from 8\% in 1995-97 to 4\% in 2005-07, in Brazil it averaged 6\% in 2005-07 up from -5\% in 1995-97, and in China increased from $3 \%$ in $1995-97$ to $9 \%$ in 2005-07. The levels are considerably lower than the OECD average of 26\% in 2005-07 (OECD, 2009b).

The combined impact of these trade-distorting agriculture policies has reduced the efficiency of agriculture production globally, particularly in the developing world. These policies are also welfare redistributing and inherently discriminatory. They promote less efficient production in developed countries. This is at the cost of investment in generally more efficient production in developing countries. The result is both global agriculture production and world food commodity prices have been depressed at a low level, and domestic food commodity prices in protected markets have been kept artificially high. In addition, because agricultural production has taken place in relatively inefficient, global trade in food products is less stable to exogenous shocks and less able to handle volatility in terms of trade, demand and output.

If these distortions are eliminated or reduced, it will better the world. Anderson, Martin and van der Mensbrugghe (2006) suggest that a move to free merchandise trade would increase farm employment, the real value of agricultural output and exports, real returns to farm land and unskilled labor, and real net farm incomes in 
developing countries. The removal of all trade distortions together would lead to global gains of US\$287 billion per year by 2015. The gains of developing countries from improved efficiency of resources use would be US $\$ 115$ billion. Self-sufficiency for developing countries improved for most agricultural products, such as wheat and rice. For most countries, farming activities would expand rather than collapse. The shares of developing countries in global agricultural output and exports would increase, thus contributing to better their living.

\section{Background of Current WTO Agricultural Rules}

Beginning in 1947, under the General Agreement on Tariffs and Trade (GATT), international trade was moving towards freer trade. Agriculture was never outside the GATT in name. However, some exceptions for agriculture were negotiated in the 1950s. This meant that the regular GATT rules did not apply to agriculture. Thus, to a large extent agriculture was excluded from the liberalization process.

These exceptions provided legal cover to some countries. They could afford to apply import restrictions, subsidize production without limit, and thus creating structural surpluses products. These structural surpluses had to be disposed somehow. Then, export subsidies and food aid turned out to be key instruments. The agricultural trade war was on the string of the bow.

Let's take a look at Figure 2, when the Uruguay Round was launched in 1986, the food commodity prices were historically low. Rice was US\$195.7 per ton, wheat was US\$114.9 per ton, maize was US\$87.8 per ton, and soybeans was US $\$ 188.9$ per ton as compared to at US\$332.4 per ton, US $\$ 255.2$ per ton, US $\$ 163.3$ per ton and US\$317.3 per ton in 2007 respectively, not to mention the prices during early 2008 .

And, the world was holding more than one-third of a year's production of wheat in storage and more than 40 percent of a year's production of corn in storage at that time (Keilke, 2008). The developed world was engaged in the competitive subsidization of agricultural exports in an attempt to dispose of products overproduced. Developing country exporters were caught in the cross-fire of a battle between developed countries.

All these became unacceptable to the global community, and even to those that were engaged in these subsidy races. That was when the Uruguay Round was launched, with the objective in agriculture of "the urgent need to bring more discipline and predictability to world agricultural trade by correcting and preventing restrictions and distortions including those related to structural surpluses so as to reduce the uncertainty, imbalances and instability in world agricultural markets" (Punta del Este Declaration launching the Uruguay Round in 1986). One of the outcomes of the nearly-eight-year negotiation was the Uruguay Round Agreement on Agriculture (URAoA), which was built on the so-called "three pillars": market access, domestic support and export competition.

Given the context and the objective, the URAoA and its built-in agenda for the continuation of the reform process was to address problems of overproduction and putt limits on domestic and export subsidies. No equal concern and interests was given to all the three pillars. And among the three pillars, export competition was poorly discussed and prescribed in the text. The URAoA made a considerable progress in market access and domestic support and more is being done in the DDA.

Developing countries agreed to the same production restraining objectives of the URAoA. Paradoxically, the majority of them suffered from the opposite problem, i.e. underproduction, as a result of their agricultural policies. For the past decades, agricultural policy in developing countries has often involved taxes on primary agriculture with the revenue being used to fund food subsidies for the urban citizens. This was opposite to what happened in the developed countries, where considerable support and protection were provided to the agricultural sector.

Although depressed prices have been the predominant state of world markets over the last 40 years, this has not always been the case as the price spikes occurred periodically. But, it was not seen by all participants in the world food market. Therefore, not enough attention was given to how to regulate agricultural trade when prices of agricultural commodities rise.

\section{WTO Rules Regarding Export Restrictions}

The main instruments and related WTO provisions fall into three general categories as regards their effects on the countries, their possible impact on the world market of food commodities and their possible unintentional effects on third countries (Sharma and Konandreas, 2008). 
In the first category are defensive measures that promote freer trade. An example of such measures is reduction of import tariffs. The second category is defensive measures that lower the ability of other countries to meet their food import needs. Export prohibitions and restrictions is an example of measures under this category. And the third category comprises measures which are relatively neutral. An example here is domestic stockholding operations.

In principle, import tariffs have a role to play in reducing the domestic price of imported foodstuffs during years of high world market prices. However, it was noted that applied import duties on basic foodstuffs are generally low. They were already low in 2007 , in the 5-10\% range, in a majority of low-income food-deficit countries. Lowering or eliminating import tariffs could counterbalance only a small part of the large increases in food. In view of the small margin in reducing import tariffs, the effect of this measure on the world market is small.

As mentioned earlier, the WTO has set the rules for trade in low price environment. But as the rule setting body, it would have had the reasonable ability to see the opposite situation, and set rules for it. In fact, the WTO does have rules governing what members can do when they impose trade restrictions in response to higher world market prices.

However, these rules are very weak in effect. Export prohibitions, restrictions and export taxation are technically legal under the WTO rules. The rules in the URAoA do not prevent countries from imposing export restrictions; and export taxation is not even disciplined at all. Many countries have resort to such measures during recent food commodity price spike. The high percentages of countries taken these measures reflect the ease of use and politically expediency of it.

\section{1) Current Rules in the WTO Texts}

What is said of export restrictions in the WTO texts actually? As regarding agricultural trade, the provisions on export restrictions in the WTO texts can be found in three Articles.

Firstly, Article XI (part 2(a)) of GATT 1994 General Elimination of Quantitative Restrictions states that the general prohibition on the use of export restrictions; Secondly, Article XX (part (i) and (j)) of GATT 1994 General Exceptions which states the exceptions for all products; Thirdly, Article 12 of the URAoA deals with Disciplines on Export Prohibitions and Restrictions.

2) What's in these Texts?

Paragraph 1 of GATT Article XI indeed forbids prohibitions or restrictions on exports other than through duties and taxes. In this sense, this Article seems to be quite restrictive though export taxation is not prohibited. However, Paragraph 2(a) makes an important exception to this general rule. It reads that Paragraph 1 shall not apply to "export prohibitions or restrictions temporarily applied to prevent or relieve critical shortages of foodstuffs or other products essential to the exporting contracting party".

That is, when one member suffers from food shortage because of low production or rising price, it can impose restrictions on exports by means of not only export taxation but also license and quota, and others. The question here is that it is not clear how to define "critical shortage".

Further, Article XX of GATT 1994 states that as long as the measures taken do not result in "arbitrary or unjustifiable discrimination among countries, or a disguised restriction on trade", countries are allowed to use measures of export restrictions "as part of a governmental stabilization plan" or "to the acquisition or distribution of products in general or local short supply". This expands the policy space to the Members.

The link of agricultural trade to these provisions is Article 12 of the URAoA. Thought titled "Disciplines on Export Prohibitions and Restrictions", this Article indicates permission to use export prohibitions or restrictions on basic foodstuffs "temporarily" to "prevent or relieve critical shortages of foodstuffs". Both the terms "critical shortage" and "temporary" are not defined here or anywhere else. And, the provisions in Article 12 of the URAoA call for Members to give "due consideration" to other members' food security needs and advance notification and consultation.

These are only moral restraint on the exporter without any concrete meaning to some extent. It is not clear to what extent any of the WTO Members that resorted to export prohibitions or restrictions recently gave due consideration importing Members' food security. 
Article 12(2) of the URAoA further exempts developing country Members from the general rule in Article 12(1), unless they are "net food exporters of the specific foodstuff concerned". Some developing countries are now significant exporters of basic foodstuffs and they should obey Article 12(1). However, this means very little in practical terms. It is impractical to set criteria for or to list net food exporting developing countries for specific products. Should there be a base period as in market access rules to decide who is a net exporting country? The situation may change when this country suffer from the so-called "critical shortage".

Thus, although WTO does have provisions governing export restriction, essentially and technically, current WTO rules allow countries to use export restrictions when they face a domestic shortage. Export taxation is never forbidden, and it could be high enough to prohibit exports.

3) What's New in the Texts under Negotiation?

Launched in 2001, the Doha Round or Doha Development Agenda (DDA) is already "eighteen years old". During the proposal stage (stage 1 and stage 2, March 2000 - March 2002), several countries including Canada, Switzerland, Korea, Japan and the United States, did propose to strengthen the rules on export restrictions during the DDA (WTO, 2004). Japan (WTO 2000) put forward the most comprehensive proposal to convert all export prohibitions and restrictions to export taxes that would be bound and reduced, plus the development of rules that could be used in the application of emergency measures.

But not all countries agree on this. In the Modalities Overview Paper circulated in December 2002, it is said, "Some participants consider that export restrictions and, in particular, export taxes are not part of the negotiations on agriculture", "other participants have submitted specific proposals to strengthen the existing disciplines under Article 12 of the Agreement on Agriculture". ${ }^{3}$

And, it seems the DDA is still not interested in this and no much attention is given to it. In the First Draft of the Modalities Phase circulated in February 2003, only one sentence was given to export restriction, "Except as provided for in paragraph 2(a) and 2(b) of Article XI and Articles XX and XXI of GATT 1994, the institution of new export prohibitions, restrictions or taxes on foodstuffs shall be prohibited". ${ }^{5}$ The revisions of this draft kept these words unchanged.

The July Package 2004 (a.k.a. Doha Work Programme) added the phrase "differential export taxes" without any definition or explanation to it under the labeled "issues of interest but not agreed", in addition to a more simple sentence to the previous wording "Disciplines on export prohibitions and restrictions in Article 12.1 of the Agreement on Agriculture will be strengthened" . ${ }^{6}$ More than one year later, in the Hong Kong Ministerial Declaration, December 2005, "differential export taxes" was still "remain of interest but not agreed" and there was "not advanced materially" on export restrictions.

The Draft Modalities (version 2006) circulated in June 2006 advanced materially in this regards with an annex: "Article 12.1 of the Agreement on Agriculture shall be amended to include the measures set out in Annex L". 8 But this paragraph was in a bracket, meaning it was not agreed. Annex L said, "In order to strengthen the existing disciplines on export prohibitions and restrictions of Article XI of GATT 1994, Article 12 of the Agreement on Agriculture shall be modified to include the following elements." 9 The annex listed six points without concrete obligations on members.

In the revised Draft Modalities in 2007 and 2008, the annex was incorporated into the main text, with slight modifications in words in different versions. And still "differential export taxes" is undefined and no more words on it. ${ }^{10}$ The latest version was issued in December 2008. The new rules augment Article 12 of the URAoA by adding provisions that require Members to follow.

\footnotetext{
${ }^{3}$ See paragraph 39, http://www.wto.org/english/tratop_e/agric_e/negoti_modoverview_e.htm.

${ }^{4}$ See paragraph 38, http://www.wto.org/english/tratop_e/agric_e/negoti_mod1stdraft_e.htm.

${ }^{5}$ Article XXI of GATT 1994 is on Security Exceptions.

${ }^{6}$ See paragraphs 49 and 50, http://www.wto.org/english/tratop_e/dda_e/draft_text_gc_dg_31july04_e.htm.

${ }^{7}$ See paragraphs 24 and 25, http://www.wto.org/english/thewto_e/minist_e/min05_e/final_annex_e.htm\#annexa.

${ }^{8}$ See paragraph 116, http://www.wto.org/english/tratop_e/agric_e/mod_ag_2006_e.htm.

${ }^{9}$ See http://www.wto.org/english/tratop_e/agric_e/mod_annex_2006_e.htm\#annexl.

10 For details of these revisions, please refer to the WTO website, http://www.wto.org/english/tratop_e/agric_e/agchairtxt_1aug07_e.htm (version 2007) and http://www.wto.org/english/tratop_e/agric_e/chair_texts08_e.htm (versions 2008).
} 
One interesting point from the last two paragraphs is that members are required to eliminate existing export prohibition and restrictions but are entitled to impose new ones.

In conclusion, the latest text of the draft Modalities, and the earlier versions as well, suggest that the status quo on this issue of export restriction is likely to continue. Considering their absence from the Articles and new provisions mentioned above, stricter rules cannot be instituted during the DDA. And more importantly, Article 12 of the URAoA is unlikely to delink from that important exception to export restrictions stipulated in the GATT 1994. And thirdly, it is also unlikely that the developing countries that are significant net food exporters will be subject to tighter disciplines, as this was not mention in all versions of the Draft Modalities.

The danger of a weak Article 12 is to raise doubts about the world market being a reliable source of food supplies (Konandreas, 2008). Strengthening Article 12, beyond what is envisaged in the draft Modalities text, and making non-compliance actionable on the part of affected WTO Members should be a priority under the current Doha Round.

\section{Discussions}

The latest texts are those concluded in Bali Package 2013 and Nairobi Package in 2015, while the Buenos Aires Ministerial Conference 2017 ended only with decisions on fish subsidies, e-commerce duties. The Ministerial Conference did not announce any package.

The Bali Package states, "We recognize the decrease in recent years in the use of export subsidies subject to reduction commitments under the Agreement on Agriculture, as indicated by information contained in Members' notifications to the WTO, and the positive developments that have also taken place in other areas of the export competition pillar." 11 The Nairobi Package says, "Developed Members shall immediately eliminate their remaining scheduled export subsidy entitlements as of the date of adoption of this Decision; Developing country Members shall eliminate their export subsidy entitlements by the end of 2018." 12 The Buenos Aires MC11 2017 issued a briefing note on agriculture issues. It mentioned the four proposals put forward by the members. ${ }^{13}$ No agreement has been reached in MC11 (Beunos Aires 2017).

From these texts and briefing notes, it not clear what the URAoA has been reformed, and how its Article 12 has been modified. Even the Bali Package and Nairobi Package do not specify how members eliminate their remaining scheduled export subsidy, what the measures are, etc. The MC9 (Bali 2013) Ministerial Decision agreed on public stockholding for food security purposes, and a further decision was made in $2014 .{ }^{14}$ This is of course good for countries in short of food to keep food security.

The ongoing WTO trade negotiations are being conducted during the agriculture product price spikes, while previous agricultural trade negotiations were conducted when global prices were lower. They focused on policies that reduced demand in other countries through protection. Now there seems to be more interest in policies that may artificially restrict supply to other countries or expand demand in some countries. What characterizes the 2007-2008 food crisis was that it followed a period during which agriculture was largely abandoned by many governments because of a generalized change in the development strategies adopted by most countries.

The price increase experienced in 2010-2011 is also in part a result of policies in a different nature. Among others, policies of importance in 2010-2011 are limitation or ban of exports, relative reduction of incentives for the production of wheat in the EU and the US, policies to stimulate consumption following the economic crisis of 2008-2009. Due to the high commodity prices in recent years, many countries have significantly reduced their export subsidies and only a handful of WTO members still use export subsidies, according to a WTO survey in 2015. ${ }^{15}$ In times of low prices, however, countries often resort to export subsidies - and history has shown that once one country does so, others would quickly follow suit.

\footnotetext{
11 For details of these revisions, please refer to the WTO website, https://www.wto.org/english/thewto_e/minist_e/mc9_e/desci40_e.htm. (Accessed on Oct 10 2018).

${ }^{12}$ For details of these revisions, please refer to the WTO website, https://www.wto.org/english/thewto_e/minist_e/mc10_e/1980_e.htm. (Accessed on Oct 10 2018).

${ }^{13}$ For details of these revisions, please refer to the WTO website, https://www.wto.org/english/thewto_e/minist_e/mc11_e/briefing_notes_e/bfagric_e.htm. (Accessed on Oct 10 2018).

${ }_{14}$ For details of these revisions, please refer to the WTO website, https://www.wto.org/english/thewto_e/minist_e/mc9_e/desci38_e.htm and https://www.wto.org/english/thewto_e/minist_e/mc9_e/nov14stockholding_e.htm. (Accessed on Oct 10 2018)

${ }^{15}$ For details of these revisions, please refer to the WTO website, https://docs.wto.org/dol2festaff/Pages/SS/directdoc.aspx?filename=q:/G/AG/W125R3.pdf. (Accessed on Oct 10 2018).
} 


\section{Conclusion}

The surge in global food prices is not alone in the historical context. Though many factors contributed to it, it has its origins in long-term trade policies that led to thin and potentially volatile markets, especially in the developing world. Then, the sudden emergence of other factors - energy price increases and demand for biofuels, drought, and short term policy responses - provided the occurrence for today's crisis.

As mentioned in the Introduction, it is not a food shortage on the global basis. Agricultural production is capable of rising, and is capable of keeping pace with rising demand for food. However, to translate the capability at global level into national level, the trade restrictions and unfair distortions that impede food production and trade must be eliminated or reduced. Distorting trade policy and policies protecting agriculture may be harmful to the poor. The most effective trade policy response to high food prices over the long term is greater liberalization around the world, reducing trade-distorting subsidies and tariffs, and strengthening WTO rules on export restrictions. For its effectiveness, trade liberalization needs to be complemented by other domestic policies aiming at increasing agricultural productivity, linking rural communities to markets, and ensuring that poor benefit from trade liberalization.

While the WTO cannot provide anything immediately to help solve the current food crisis, the WTO Doha Round of trade negotiations can be part of the medium-to-long term response to the food price crisis (WTO, 2008b). Therefore, greater commitment to multilateral trade rules should strengthen during the Doha Round that discipline border barriers, domestic support, export subsidies, and export restrictions.

\section{References}

1. Anderson, Kym and Ernesto Valenzuela (2008). Estimates of Global Distortions to Agricultural Incentives, 1955 to 2007, World Bank, Washington DC, October 2008, data available at http://ww.worldbank.org/agdistortions.

2. Anderson, Kym, Marianne Kurzweil, Will Martin, Damiano Sandri, and Ernesto Valenzuela (2008). "Measuring Distortions to Agriculture Incentives, Revisited. Policy Research Working Paper 4612, World Bank, Washington, D.C., USA.

3. Anderson, Kym, Will Martin and Dominique van der Mensbrugghe (2006). Distortions to world trade: impacts on agricultural markets and farm incomes. Review of Agricultural Economics, 28(2), 168-194.

4. Bhagwati, J. N. (1971). The Generalized Theory of Distortions and Welfare. In Trade, Balance of payments and Growth, ed. J. N. Bhagwati et al. Amsterdam, Netherlands: North-Holland.

5. Chauffour, Jean-Pierre (2008). Global Food Price Crisis: Trade Policy Origins and Options. World Bank Trade Note No. 34, July, Washington D.C., USA.

6. FAO (2008a). Soaring Food prices: fact, Perspectives, Impacts and Actions Required. Document of the High-level Conference on World Food Security: the Challenges of Climate Change and Bioenergy, June, Rome, Italy.

7. FAO (2008b). National Policy Responses to high Food Prices. FAO Economic and Social perspectives Policy Brief No. 1, July, Rome, Italy.

8. IMF (2008). IMF Helping Countries Respond to Food Price Crisis. IMF Survey Online, http://www.imf.org/external/pubs/ft/survey/so/2008/NEW060308A.htm, June. Accessed on $20^{\text {th }}$ November, 2008.

9. Konandreas, P. (2008). Soaring World Food Prices: Causes and Some Important Trade Policy Response. Presented at the Round Table on the Changing Face of Commodities in the Twenty-first Century, UNCTAD XII Accra, April 2008.

10. Lin, Justin (2008). Prepared Remarks for the Roundtable on 'Preparing for the next Global Food Crisis'. Center for Global Development, October, Washington D.C., USA.

11. Meilke, Karl (2008). Did the WTO Play a Role in the Food Crisis? Canadian Agricultural trade Policy Research Network Commissioned Paper No. 2008-03, Vancouver, Canada.

12. Mitchell, Donald (2008). A Note on Rising Food Prices. Policy Research Working Paper No 4682, World Bank, Washington, DC.

13. OECD (2009a). Agricultural Policies in OECD Countries: Monitoring and Evaluation 2009, Paris, France.

14. OECD (2009b). Agricultural Policies in Emerging Economies: Monitoring and Evaluation 2009, Paris, France. 
15. Piesse, Jenifer and Colin Thirtle (2009). Three bubbles and a panic: An explanatory review of recent food commodity price events. Food Policy, 34(2), 119-129.

16. Sen, Amartya (1981). Poverty and Famines: An Essay on Entitlement and Deprivation, Oxford: Clarendon Press.

17. Sharma, Ramesh and Panos Konandreas (2008). WTO Provisions in the Context of Responding to Soaring Food Prices. FAO Commodity and Trade Policy Research Working Paper No. 25, October, Rome, Italy.

18. Trostle, Ronald (2008). Global Agricultural Supply and Demand: Factors Contributing to the Recent Increase in Food Commodity Prices, US Department of Agriculture Economic Research Service Reports No. WRS200801, July, Washington D.C., USA.

19. World Bank (2008a). Addressing the Food Prices: The Need for Rapid and Coordinated Action. Background Paper to Group of Eight Meeting of Financial Ministers, June, Osaka, Japan.

20. World Bank (2008b). Global Monitoring Report 2008, February, Washington D.C., USA.

21. WTO (2000). Negotiating Proposal by Japan on WTO Agricultural Negotiations, G/AG/NG/W/91, 21 December.

22. WTO (2004). WTO Agricultural Negotiations: the Issues, and Where are We Now? December, Geneva, Switzerland.

23. WTO (2008a). World Tariff Profiles 2008, Geneva, Switzerland.

24. WTO (2008b). Statement by Pascal Lamy at the Rome Food Summit, June, Rome, Italy.

25. WTO (2018). World Tariff Profiles 2018, Geneva, Switzerland. 